\title{
Effect of irrigation scheduling on canopy cover development and crop-water management related parameters of $O$.ficus-indica under prolonged drought conditions.
}

\author{
${ }^{*}$ Maha Elbana1, Eman H. El-Gamal², Abdallah E. Mohamed², Ana Luisa Fernando ${ }^{3}$, Luigi \\ Pari $^{4}$, Abdelkader Outzourhit ${ }^{5}$, Mahmoud Elwakeel ${ }^{6}$, Wael E.A. El-Sheikh ${ }^{7}$ and Mohamed \\ $\operatorname{Rashad}^{2}$
}

\begin{abstract}
${ }^{1}$ Soil and Water Science Department, Faculty of Agriculture, Beni-Suef University, Beni-Suef 62511, Egypt, ${ }^{2}$ Land and Water Technologies Department, Arid Lands Cultivation Research Institute, City of Scientific Research and Technological Applications (SRTA-City), New Borg Elarab, Alexandria, Egypt, ${ }^{3}$ University Nova de Lisboa, Faculty of Science and Technology, Department of Biomass Science and Technology, Environmental Biotechnology Unit, 2829-516 Caparica, Portugal, ${ }^{4}$ Council for Agricultural Research and Economics, Research Center for Engineering and Agro-Food Processing (CREA-IT), Via della Pascolare, 16, 00015 Monterotondo, Italy, ${ }^{5}$ Cadi Ayyad University, Marrakech, Morocco, ${ }^{6}$ Food Science Department, Faculty of Agriculture, Beni-Suef University, Beni-Suef 62511, Egypt, ${ }^{7}$ Department of Plant Protection, Faculty of Agriculture, Beni-Suef University, Beni-Suef 62511, Egypt

* Corresponding author: maha.elbana@agr.bsu.edu.eg
\end{abstract}

Received on: 21/11/2020

Accepted on: 10/12/2020

\begin{abstract}
Opuntia ficus-indica is gaining scientists' and policy makers' interest worldwide as drought tolerant crop adopted to marginal low fertile soils. Few studies were conducted to estimate its water management parameters under different soil-climate conditions. O.ficus-indica was planted in the experimental farm of City of Scientific Research and Technological Applications (SRTA-City, Alexandria, Egypt) under different irrigation scheduling applications. The study aimed to understand the effect of severe water deficit on crop development and water management related parameters. First irrigation scheduling (T1) applied irrigation with fixed amount of water $\left(7.2 \mathrm{~m}^{3} \mathrm{ha}^{-1}\right.$ week $\left.^{-1}\right)$. The second (T2), was applied when soil water content (SWC) became below 35\% of field capacity $\left(\Theta_{\mathrm{fc}}\right)$ in effective root zone. The third (T3), was conducted when SWC was below $30 \%$ of $\Theta_{\text {fc. }}$ The results revealed higher yield under T1 than T2 and T3. Water productivity was the lowest in $\mathrm{T} 1\left(0.62 \mathrm{~kg} \mathrm{~m}^{-3}\right)$ and the highest in $\mathrm{T} 3\left(18.13 \mathrm{~kg} \mathrm{~m}^{-3}\right)$. Actual crop evapotranspiration $\left(\mathrm{ET}_{\mathrm{a}}\right)$ was significantly higher in T3 $\left(4.80 \mathrm{~mm} \mathrm{day}^{-1}\right)$, than T2 $\left(4.56 \mathrm{~mm} \mathrm{day}^{-1}\right)$ and T1 $\left(3.84 \mathrm{~mm} \mathrm{day}^{-1}\right)$. No significant difference was found in soil water content, canopy cover, crop coefficient among the applied irrigation scheduling. Average canopy cover was $13.63 \%, 11.08 \%$, and $10.22 \%$ for $\mathrm{T} 1$, T2, and T3, respectively indicating early crop development stage. The corresponding crop coefficient $(\mathrm{kc})$ was between 0.19 in $\mathrm{T} 1$ to 0.23 in T2 and 0.24 in T3. Further study is recommended to confirm obtained results and estimate $\mathrm{ET}_{\mathrm{a}}$ and $\mathrm{kc}$ under middle and end crop development stages.
\end{abstract}

KEYWORDS: Cactus pear, water management, actual evapotranspiration, crop coefficient, digital image processing

\section{INTRODUCTION}

Countries located in arid zones, such as Egypt, suffer limited water resources. The irrigated area in Egypt was $\sim 3.76$ million hectares in 2013 (MALR, 2014) that is threatened to be decreased due to illegal urbanization and land misuse. The agricultural sector in Egypt consumes about $85 \%$ of conventional available water (MWRI, 2014). The majority of Egyptian territory is desert, and rangelands that covers an area of about 100 million hectares (Kumar et al., 2018) with severe shortage in water supply. Planting well adapted crops to harsh environmental conditions in the Mediterranean area, especially in arid marginal lands, would positively contribute to more food security. However, this must not apply more pressure on already restricted water resources in these areas. Opuntia spp. Started to form part of the agricultural system (Inglese et al., 2017, Kumar et al., 2018). Opuntia ficus-indica (O.ficus-indica), in particular, is one of the most important species of cactaceae family worldwide from the economic point of view (Kiesling, 1998). In Africa, it is well adopted in Algeria, Morocco, Tunisia, South Africa, and Ethiopia (Inglese et al., 2017). In Egypt, it is usually grown in sandy soils (Abo-El-Ela et al., 2001) especially in Giza, Menofyia, Ismailia, Sharkia, and Behira (Ammar et al., 2004). The interest of planting O.ficus-indica in Egypt is increasing year after 


\section{Scientific Journal of Agricultural Sciences 2 (2): 113-122, 2020}

another. The total cultivated area of $O$.ficus-indica in Egypt augmented from 650 ha in 1994 to 2550 ha in 2002 (Sáenz et al., 2013) and to 6000 ha in 2008 (Bakr, 2019). This is mainly due to the Egyptian policy that promoted cultivation of cactus pear (O.ficus-indica) in desert settlements to cope with climate change and empower women contribution to agricultural sector in these areas (Najjar, 2015). In the harvest season, in Egypt, the major percent of O.ficusindica produced fruit is distributed by numerous vendors in street sides and consumed directly fresh and peeled. However, little information is available about commercial cultivation and production of Cactus pear worldwide (Sáenz et al., 2013). Several studies focused on O.ficus-indica as part of the agricultural system. Part of these studies focused mainly on crop origin, geographical distribution, and ecology (Kiesling, 1998; Inglese, et al., 2017, Kumar et al., 2018). Other studies were concerned about social impact of cactus pear plantation in marginal lands that empowered women contribution to agricultural production system (Najjar, 2015). Further studies provided good manual for the proper cultivation methods for O.ficus-indica (CAAES, 2005; Liguori and Inglese, 2015; Inglese et al., 2017) and its contribution as forage to animal production (Bakr, 2019). Khalafalla et al. (2016) recorded 71 species associated with O.ficus-indica in their vegetation analysis of plant species linked to the crop. Ammar et al. (2004) studied the major pathogens in Egypt that provoke cladode and fruit rots of O.ficusindica. They found that Fusarium solani, Alternaria alternata, and Botryodiplodia theobromae are the main causes for plant rotting. Further studies reported the industrial uses of the crop as juices, jams, pharmaceutical products, etc. (Sáenz et al., 2013; Inglese et al., 2017; Kumar et al., 2018). From the onfarm water management point of view, Snyman (2005) reported that the majority of O.ficus-indica root mass was concentrated in the first $100 \mathrm{~mm}$ of soil profile at the beginning of the experiment and extended to reach $\sim 1.8 \mathrm{~m}$ after the first growing season. This coincided with the observations of North and Nobel (1992) who indicated that the plant roots of O.ficus-indica could reach 4-8 m depth beneath soil surface. Yet, according to Snyman (2005) and Inglese et al. (2017), its effective root zone did not exceed $0.30 \mathrm{~m}$ depth in the soil under the most adequate growth conditions. Actual evapotranspiration $\left(\mathrm{ET}_{\mathrm{a}}\right)$ as well as crop coefficient (kc) were estimated by Consoli et al. (2013) for O.ficus-indica. They applied a micrometeorological method to conduct their study. They found that average daily $\mathrm{ET}_{\mathrm{a}}$ and $\mathrm{kc}$ were $2.5 \mathrm{~mm}$ and 0.40 , respectively when average reference evapotranspiration $\left(\mathrm{ET}_{\mathrm{o}}\right)$ was $5.0 \mathrm{~mm}$. There are multiple methods to determine crop $\mathrm{ET}_{\mathrm{a}}$ and its relationship with soil water content (SWC). Jung et al. (2010) conducted their study based on meteorological data and remote sensed $\mathrm{ET}_{\mathrm{a}}$ and $\mathrm{SWC}$ values. They reported that global $\mathrm{ET}_{\mathrm{a}}$ was affected negatively when soil water supply was limited. Duffková et al. (2011) used energy balance equation to estimate $\mathrm{ET}_{\mathrm{a}}$ for different crops in different soil types, slopes, and properties. They found that soil properties had influence on $\mathrm{ET}_{\mathrm{a}}$ especially during crop maturity stage and drought conditions. They indicated that $\mathrm{ET}_{\mathrm{a}}$ was significantly lower in coursetextured soil than fine-texture one. Graf et al. (2014) conducted a three years study from 2010 to 2013 to estimate SWC applying the wavelet coherence analysis. They conducted their study based on soil water balance model including precipitation $(\mathrm{P}), \mathrm{ET}_{\mathrm{a}}$, $\mathrm{ET}_{\mathrm{o}}$ and runoff. They found a relationship between soil water storage and the output of $\mathrm{P}^{-E^{2}} \mathrm{~T}_{\mathrm{a}}$-runoff. They also reported that $\mathrm{ET}_{\mathrm{a}} / \mathrm{ET}_{\mathrm{o}}$ ratio was affected positively by available water content in soil profile. Filgueiras et al. (2020) used regression algorithms and remote sensed vegetation index for maize crop to estimate $\mathrm{ET}_{\mathrm{a}}$ and $\mathrm{SWC}$ for low-cost irrigation management. Their produced fitted models revealed the viability of vegetation index as information tool to increase the reliability of $\mathrm{ET}_{\mathrm{a}}$ and $\mathrm{SWC}$ estimation and modelling. Rahmati et al. (2020) used lysimeter to estimate grassland $\mathrm{ET}_{\mathrm{a}}$ and understand its relationship with SWC based on soil water balance method collecting data from 2012 to 2018. They reported strong relationship between $\mathrm{ET}_{\mathrm{a}}$ and SWC, that was higher in dryer soils than wet soils. However, Seneviratne et al. (2010) reported in their literature review about the relationship between $\mathrm{SWC}$ and $\mathrm{ET}_{\mathrm{a}}$ the high uncertainty level of the influence degree of

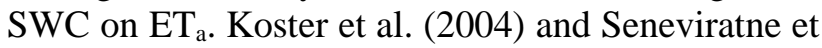
al. (2006) indicated that the higher influence of SWC on $\mathrm{ET}_{\mathrm{a}}$ was observed when SWC reached the critical level were below this level the crop starts to suffer some constraints in its $\mathrm{ET}_{\mathrm{a}}$ process. They classified soil moisture availability to three main regimes: i) Wet regime, where SWC is higher than the critical level, ii) Dry regime, where SWC is lower than the wilting point, and iii) the Transitional regime, where SWC falls in between the "Wet" and "Dry" regimes. They found that the major influence of SWC on $\mathrm{ET}_{\mathrm{a}}$ was observed in the transitional regime. Fluctuation of SWC under this regime, resulted in fluctuation of $\mathrm{ET}_{\mathrm{a}}$. Yet, they reported that both "Wet" and "Dry" regimes did not influence $\mathrm{ET}_{\mathrm{a}}$. Studies also proved that O.ficus-indica could survive extreme drought conditions in arid and semi-arid soil and climate conditions. Souza et al. (2020) applied no irrigation or fertilization during two successive years (October 2015-August 2017) to study the effect of prolonged drought periods on "Gigante" O.ficus-indica yield and survival rate. They applied, in their study, six 
different treatments (i) no fertilization+no irrigation, (ii) no fertilization+0.6 L Plant ${ }^{-1} \mathrm{Week}^{-1}$, (iii) no fertilization+1.2 L Plant $^{-1} \quad$ Week $^{-1}$, (iv) no fertilization+1.2 $\mathrm{L} \mathrm{Plant}^{-1}$ Week $^{-1}$ (two applications per week), (v) organic fertilization+1.2 $\mathrm{L} \mathrm{Plant}^{-1}$ Week $^{-1}$, (vi) organic fertilization+no irrigation. They concluded that irrigation with $0.6 \mathrm{~L} \mathrm{Plant}^{-1}$ Week $^{-1}$ increased the productivity of $O$.ficus-indica, in terms of mass and cladodes production, than rainfed plants and augmented its survival rate. However, few studies were focused on estimating crop-water management parameters for O.ficus-indica including soil water content (SWC), crop coefficient (kc), and actual crop evapotranspiration $\left(\mathrm{ET}_{\mathrm{a}}\right)$ as relevant tools to compute crop water requirements and increase water productivity on farm level. The presented study aimed to understand the effect of different applied irrigation scheduling, in terms of applied water regime and timing, on O.ficus-indica water management parameters $\left(\mathrm{ET}_{\mathrm{a}}, \mathrm{kc}, \mathrm{SWC}\right)$ and canopy development under severe prolonged soil water deficit.

\section{MATERIAL AND METHODS}

\subsection{Experimental field setup}

The study was conducted in the experimental farm of City of Scientific Research and Technological Applications, SRTA-City (3053'33.17'N' 29²2'46" E), New Borg Elarab, Alexandria, Egypt. The study area is characterized by Mediterranean arid climate conditions. Weather data during the experiment was obtained from the nearest weather station in New Borg Elarab Airport ( $\left.31^{\circ} 13^{\prime} 12.17^{\prime \prime} \mathrm{N}, 29566^{\prime} 4^{\prime \prime} \mathrm{E}\right)$ available online at The Weather Company (CTWC Product and Technology LLC 2014, 2020). Daily reference evapotranspiration $\left(\mathrm{ET}_{\mathrm{o}}\right)$ was calculated following FAO Penman-Monteith equation according to the procedure outlined in (Allen et al., 1998) using $\mathrm{ET}_{\mathrm{o}}$ Calculator software (Version 3.2, CFAO 2012).

The experimental field was of 0.1 ha divided into 3 plots with at least $8 \mathrm{~m}$ distance from each other to avoid possible lateral flow of water among the cultivated plots. The plant cladodes were soaked in a solution of copper oxychloride $\left(1 \mathrm{~g} \mathrm{l}^{-1}\right)$ to avoid potential infections before plantation as recommended by (CAAES, 2005). The cladodes were left in well-aired shadow area for four weeks before planting date. On 24 March 2019, the cladodes were inserted into the soil letting one third above soil surface facing sun from east to west all day long. O.ficus-indica was planted in furrows and irrigated using drip irrigation system. Spacing between furrows was $4 \mathrm{~m}$ and between plants at same furrow was $3 \mathrm{~m}$. Each plant received a mix of fertilizers consisted of $12 \mathrm{~kg}$ organic compost+0.5 kg agricultural sulfur $+0.5 \mathrm{~kg}$ ammonium sulfate $+0.5 \mathrm{~kg}$ super phosphate. The fertilizer mixture was put in a $0.5 \mathrm{~m}^{3}$ hole beneath soil surface at each plant location at the beginning of the experiment. The plant was cultivated under three irrigation scheduling applications based on soil moisture depletion in effective root zone. According to the United States Department of Agriculture (USDA, 2020), soil water depletion is the amount of water needed to increase soil moisture content (SWC) in effective root zone up to field capacity. Each application was cultivated with total 60 plants divided into three replicates. In the first irrigation scheduling application (T1), the plant was irrigated once per week with $7.2 \mathrm{~m}^{3} \mathrm{ha}^{-1}$ of water as recommended by Ministry of Agriculture and Land Reclamation (CAAES, 2005). The second irrigation scheduling application (T2) was irrigated only when SWC was below $35 \%$ of field capacity $\left(\Theta_{\mathrm{fc}}\right)$ and the third application (T3) was irrigated when it got below $30 \%$ of $\Theta_{\text {fc. }}$ Every irrigation event in T2 and T3 lasted until filling effective root zone with $40 \%$ of $\Theta_{\mathrm{fc}}$. These different irrigation scheduling applications resulted in different amount of applied irrigation water and different irrigation timing. Figure 1 is a visual presentation of applied irrigation events timing under the three tested irrigation scheduling (T1, T2, and T3).

All plants received $7.2 \mathrm{~m}^{3} \mathrm{ha}^{-1}$ of water at the beginning of the experiment then applications were applied after that to ensure equal initial conditions. The plant was harvested twice on 4 August 2019 and on 27 September 2020. The effect of each applied irrigation scheduling on O.ficus-indica canopy cover development (CC), fruit yield, $\mathrm{ET}_{\mathrm{a}}, \mathrm{kc}$, and water productivity (WP) was studied. The experiment was conducted with strip plot statistical design.

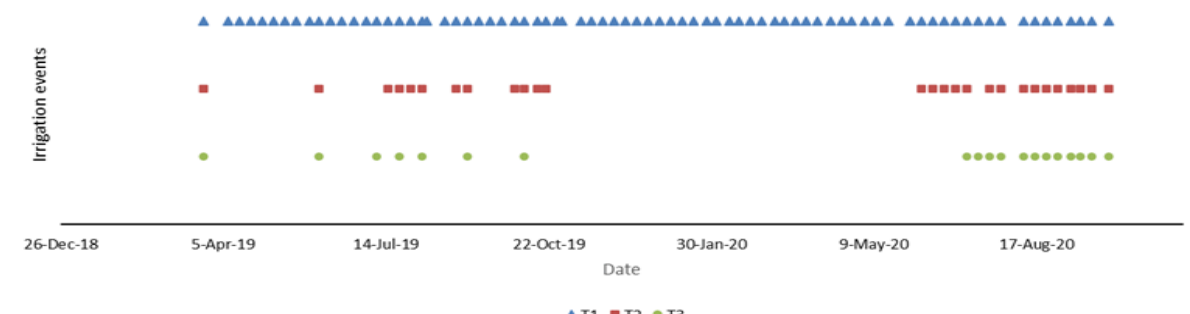

Figure 1. Date of different applied irrigation scheduling (T1, T2, and T3) during the experiment period in 2019-2020 
The One-Way Analysis of Variance (ANOVA) tool within the SPSS statistical program was used to determine significant difference in the obtained results among the applied irrigation scheduling ( $\mathrm{T} 1$, $\mathrm{T} 2$, and T3). Results were checked at 0.05 significance level.

\subsection{Soil water measurements}

Soil texture and bulk density was determined at the beginning of the experiment. Bulk density is relevant parameter to compute depth of water content in effective root zone $(25 \mathrm{~cm})$. Soil water content (SWC) at saturation, field capacity $\left(\Theta_{\mathrm{fc}}\right)$ and wilting point was determined gravimetrically following Estefan et al. (2013). SWC was determined as well on weekly basis and before each irrigation event to compute actual evapotranspiration (Michael, 2006) following Israelsen and Hansen (1962) as shown below:

$$
E T_{a}=D \times P b \times\left[\theta_{f c}-\theta_{i}\right] / 100(\text { Equation } 1)
$$

Where $\mathrm{ET}_{\mathrm{a}}$ is actual evapotranspiration by plant, $\mathrm{D}$ is soil depth $(\mathrm{cm}), \mathrm{Pb}$ is soil bulk density $\left(\mathrm{gm} \mathrm{cm}^{-3}\right), \Theta_{\mathrm{fc}}$ is percent of SWC at field capacity, $\Theta_{i}$ is percent of SWC before irrigation.

Crop coefficient $(\mathrm{Kc})$ for the planted crop was estimated during the experiment by dividing the actual evapotranspiration $\left(\mathrm{ET}_{\mathrm{a}}\right)$ by reference evapotranspiration $\left(\mathrm{ET}_{\mathrm{o}}\right)$ as explained in Equation (2).

$$
k c=E T_{a} / E T_{o} \quad \text { (Equation 2) }
$$

Water productivity (WP) for each applied irrigation scheduling was determined below following Molden et al. (2003):

$W P=Y_{a} / W_{t}$

(Equation 3)

Where $\mathrm{Y}_{\mathrm{a}}$ is the actual harvested fruit yield in kilograms and $\mathrm{W}_{\mathrm{t}}$ is total applied water in $\mathrm{m}^{3}$.

\subsection{Estimation of canopy cover development}

Various studies estimated canopy cover (CC) using digital image processing (Korhonen and Heikkinen, 2009; Lee and Lee, 2011; Alivernini et al., 2018; Xiong et al., 2019). The presented research study used Image Processing and Analysis in Java tool (Image J 1.52p software, National Institutes of Health, USA) to estimate CC from digital images. The digital photos were taken by mobile camera of 12 MP at fix height of $2 \mathrm{~m}$ on weekly basis. Three replicates per each irrigation scheduling application were taken and overall average was assessed. Brief steps for digital images processing using ImageJ tool are presented in Figure 2. Digital images were imported to ImageJ software and cropped to the center of each to avoid the error that could provoke due to lateral effect on the edges. Canopy cover area was selected using the free hand selection tool for the estimation. Then image was transformed into a binary image with 8 bits in black and white. After that, region of interest (ROI) was determined to estimate canopy cover. Once selected the ROI, the CC percentage was estimated using the area function tool of the software. The estimated area percentage is for the white pixels. To obtain the CC percentage (black area), the result was subtracted from 100.

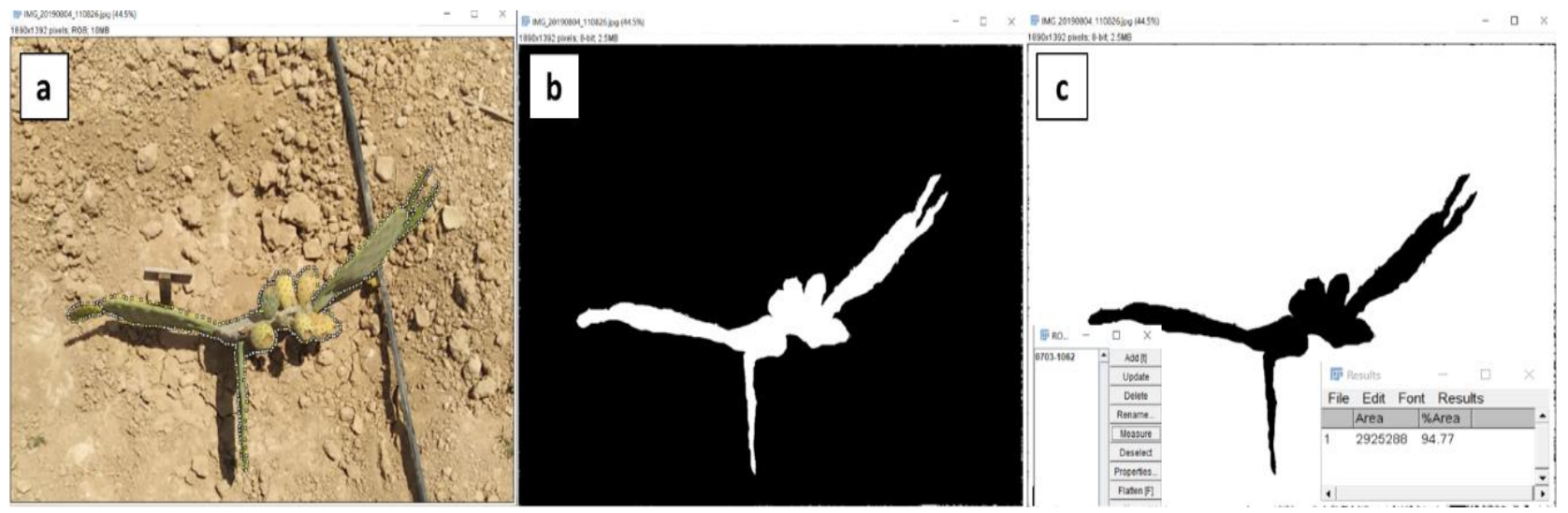

Figure 2. Digital image processing to estimate canopy cover for $O$.ficus-indica plant. a: cropped image to center and delimitation of green canopy cover, b: converting to binary image with 8 bits, c: determination of area of interest. Estimated $\mathrm{CC}=\sim \mathbf{5 . 2 3 \%}$ 
Scientific Journal of Agricultural Sciences 2 (2): 113-122, 2020

Print (ISSN 2535-1796) / Online (ISSN 2535-180X)

DOI: 10.21608/sjas.2020.50551.1061

\section{RESULTS AND DISCUSSION}

The experiment was conducted in a sandy loam soil $(65.3 \%$ sand $-18.7 \%$ clay) with bulk density of $1.56 \mathrm{~g} \mathrm{~cm}^{-3}$. SWC at saturation, field capacity, and wilting point was $42.8 \%, 22.7 \%$, and $13.4 \%$ on weight basis, respectively. Daily rainfall and minimum and maximum temperature during the experiment run in 2019 and 2020 are presented in Figure 3. Average registered minimum and maximum temperature were $15.7^{\circ} \mathrm{C}$ and $25.8{ }^{\circ} \mathrm{C}$, respectively. Total rainfall was $213.3 \mathrm{~mm}$ in 2019 and $256.0 \mathrm{~mm}$ until Nov. 2020. Precipitation is usually in winter and autumn seasons from October to March. Summer and spring seasons are usually dry and relatively hot were average rainfall is zero $\mathrm{mm}$.

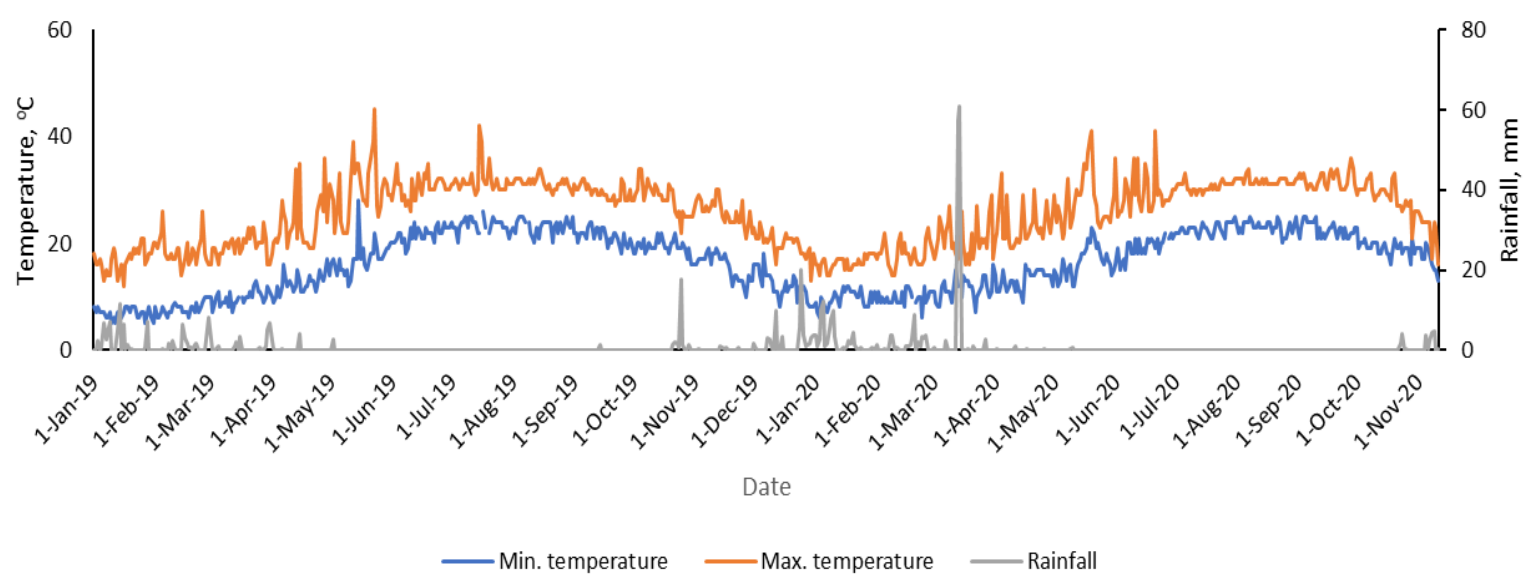

Figure 3. Daily minimum and maximum temperature $\left({ }^{\circ} \mathrm{C}\right)$ and rainfall $(\mathrm{mm})$ during the experiment run in 2019 and 2020, Alexandria, Egypt

Calculated $\mathrm{ET}_{\mathrm{o}}$ during $2019-2020$ is presented in Figure 4. $\mathrm{ET}_{\mathrm{o}}$ values varied from minimum of $0.8 \mathrm{~mm}$ day $^{-1}$ during winter cold season to a maximum of 6.0 $\mathrm{mm}$ day $^{-1}$ in summer hot season. $\mathrm{ET}_{\mathrm{o}}$ values during summer ( average $4.0 \mathrm{~mm}$ day $^{-1}$ ) are generally higher than winter ( average $1.5 \mathrm{~mm} \mathrm{day}^{-1}$ ). Allen et al. (1998) indicated that principal weather parameters

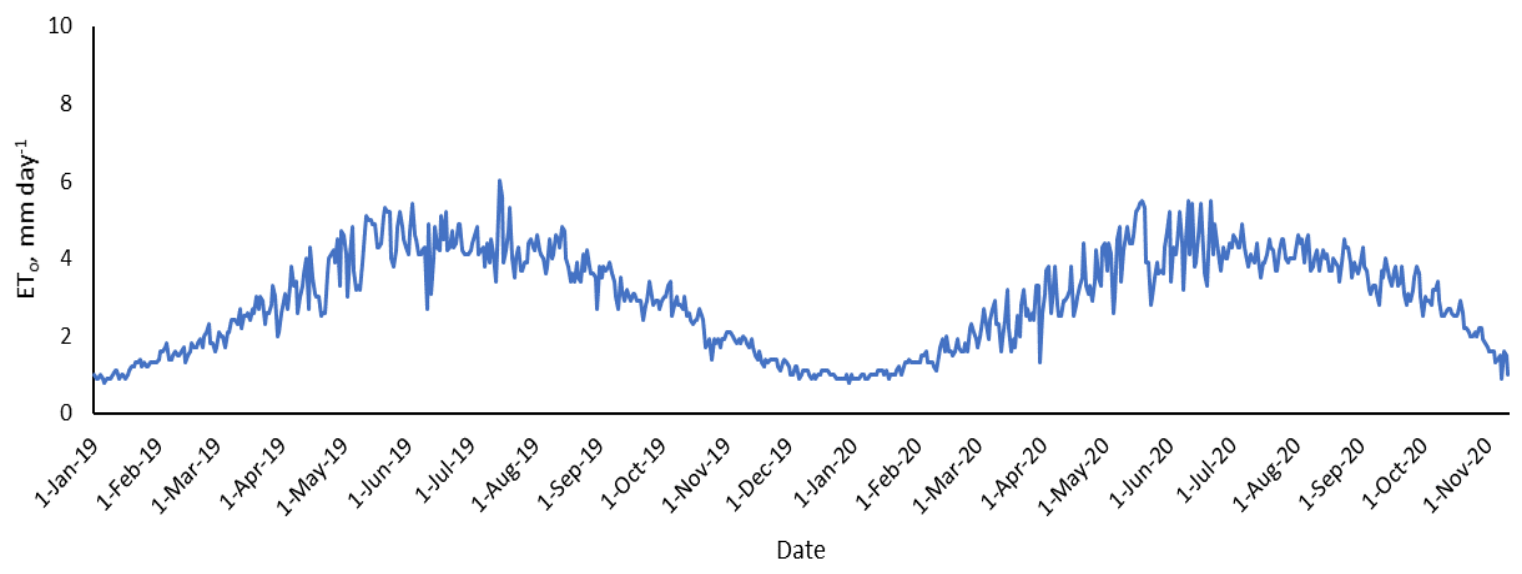

affect $\mathrm{ET}_{\mathrm{o}}$ are radiation, air temperature, humidity, and wind speed. Wang et al. (2014) found in his study on the effect of climate change over $\sim 50$ years on $\mathrm{ET}_{\mathrm{o}}$ that higher daily air temperature increased $\mathrm{ET}_{\mathrm{o}}$ values by $11 \%$. This coincided with Liu et al. (2019) who reported positive sensitivity of $\mathrm{ET}_{\mathrm{o}}$ to air temperature and average sunshine hours.

Figure 4. Reference evapotranspiration $\left(\mathrm{ET}_{\mathbf{0}}\right)$ in $\mathrm{mm} \mathrm{day}^{-1}$ along the study period in Alexandria during 2019 and 2020

Mean and standard error of soil water content (SWC) on weight basis, canopy cover (CC), fruit yield, water productivity (WP), actual evapotranspiration $\left(\mathrm{ET}_{\mathrm{a}}\right)$, and crop coefficient $(\mathrm{kc})$ for O.ficus-indica during experiment run in 2019-2020 are presented in the table below. It was found that mean SWC in $\mathrm{T} 1$ was significantly higher $(\mathrm{P} \leq 0.05)$ than T2 and T3. Meanwhile, no significant difference was observed between T2 and T3 in SWC. This might be due to the higher amount of applied irrigation water in $\mathrm{T} 1$ compared to $\mathrm{T} 2$ and $\mathrm{T} 3$. The noticed increase in total applied water for T1 $\left(554 \mathrm{~m}^{3} \mathrm{ha}^{-1}\right)$ was due to the weekly applied irrigation process with $7.2 \mathrm{~m}^{3} \mathrm{ha}^{-1}$. The total applied water for T2 and T3 was 16.62 and $12.54 \mathrm{~m}^{3} \mathrm{ha}^{-1}$, respectively. This is primarily because of applying irrigation only when SWC dropped below $35 \%$ and $30 \%$ of $\Theta_{\text {fc }}$ for T2 and $\mathrm{T} 3$, respectively. The applied $\mathrm{T} 2$ and $\mathrm{T} 3$ irrigation 
scheduling resulted in irrigating O.ficus-indica mainly during summer (Figure 1) where higher temperature, fewer precipitation (Figure 3), and higher $\mathrm{ET}_{\mathrm{o}}$ (Figure 4) than winter were recorded. In this case, precipitation supply in effective root zone in winter assisted in maintaining SWC in the chosen levels. This is also might be thanks to O.ficus-indica capacity of rapid absorption to water added to the soil, covered roots with moderately impermeable coat to water especially the fine roots in effective root zone, and its capacity to decrease shoot transpiration when needed (Passioura, 1988; Inglese et al., 2017).

Table 1. Mean \pm standard error of soil water content (SWC) on weight basis, actual evapotranspiration $\left(\right.$ ET $\left._{\mathrm{a}}\right)$, crop coefficient $(\mathrm{kc})$, canopy cover $(\mathrm{CC})$, fruit yield, and water productivity (WP) per each applied irrigation scheduling during 2019-2020.

\begin{tabular}{lllllll}
\hline Application & $\mathrm{SWC}, \%$ & $\mathrm{CC}, \%$ & $\begin{array}{l}\text { Fruit yield, } \\
\mathrm{kg} \mathrm{ha}^{-1}\end{array}$ & $\mathrm{WP}, \mathrm{kg} \mathrm{m}^{-3}$ & $\mathrm{ET}_{\mathrm{a}}, \mathrm{mm} \mathrm{day}^{-1}$ & $\mathrm{kc}$ \\
\hline T1 & $12.78 \pm 0.53^{\mathrm{a}}$ & $13.63 \pm 1.28^{\mathrm{a}}$ & 342 & 0.62 & $3.84 \pm 0.20^{\mathrm{b}}$ & $0.19 \pm 0.01^{\mathrm{a}}$ \\
T2 & $10.79 \pm 0.54^{\mathrm{b}}$ & $11.08 \pm 1.06^{\mathrm{a}}$ & 226 & 13.60 & $4.65 \pm 0.21^{\mathrm{a}}$ & $0.23 \pm 0.21^{\mathrm{a}}$ \\
T3 & $10.47 \pm 0.58^{\mathrm{b}}$ & $10.22 \pm 1.13^{\mathrm{a}}$ & 227 & 18.13 & $4.80 \pm 0.22^{\mathrm{a}}$ & $0.24 \pm 0.22^{\mathrm{a}}$ \\
\hline
\end{tabular}

Despite the observed significant difference in SWC among irrigation scheduling applications, no significant difference was found at $\mathrm{P} \leq 0.05$ in canopy cover (CC) of O.ficus-indica among the applied irrigation scheduling in T1, T2, and T3. Souza et al, (2020) also observed no significant difference in O.ficus-indica cladodes' number among the applied 4 different irrigation scheduling that varied from no irrigation at all for two successive years (2015-2017) to maximum of $1.2 \mathrm{~L} \mathrm{Plant}^{-1}$ Week $^{-1}$ when no fertilization was applied during the experiment run.
Estimated CC development for O.ficus-indica during 2019 and 2020 is presented in Figure 5. The observed drop in CC values by the end of September 2019 was due to the conducted pruning process. The plant was subjected to pruning process on 17 September 2019 after the first harvesting season. The process kept only two cladodes per each mother cladode to allow more exposure to sunlight within the canopy supporting cladodes' growth, flowering, and fruit growth (Liguori and Inglese, 2015).

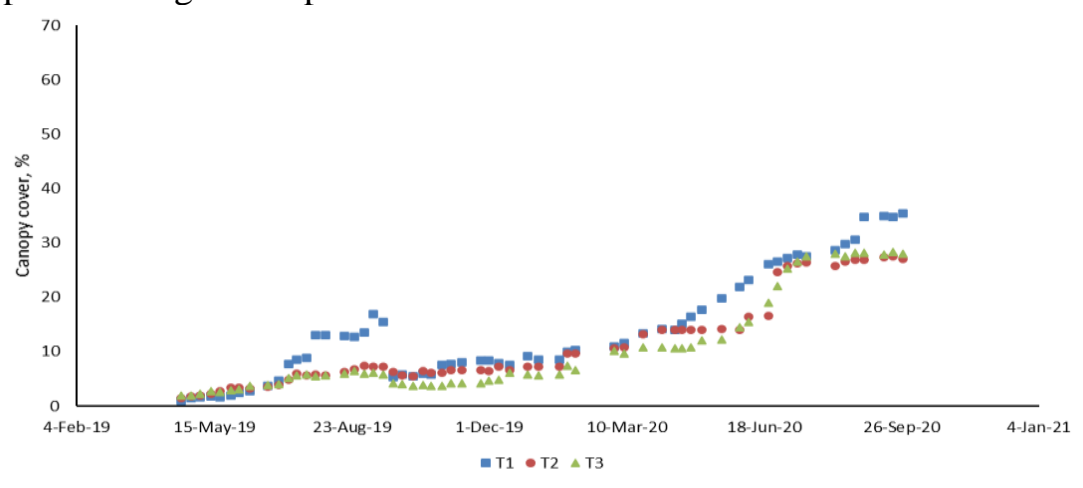

Figure 5. Estimated percentage of canopy cover development of $O$.ficus-indica during seasons 2019 and 2020 under the three applied irrigation scheduling.

Maximum canopy area percentage was $35 \%$ for $\mathrm{T} 1,27 \%$ for $\mathrm{T} 2$, and $28 \%$ for $\mathrm{T} 3$ which indicated that the plant was still in the early development stage. According to Hassan et al. (2020) study, the O.ficusindica cladodes reached their maximum surface area entirely by the end of the first growing season. In the current study, the observed increase in crop canopy cover during second season was due to the observed new cladodes generated from the mother cladode. This is also might explain the higher yield of T1 (342 $\left.\mathrm{kg} \mathrm{ha}^{-1}\right)$ than T2 $\left(226 \mathrm{~kg} \mathrm{ha}^{-1}\right)$ and T3 $\left(227 \mathrm{~kg} \mathrm{ha}^{-1}\right)$ since the higher CC in this case was function of the higher number of cladodes. The experiment is running currently for third season to study canopy cover development and growth along different growth stages in successive growing seasons. On the other hands, WP was the lowest under T1 irrigation scheduling $\left(0.62 \mathrm{~kg} \mathrm{~m}^{-3}\right)$ while $\mathrm{T} 3$ resulted in the highest WP $\left(18.13 \mathrm{~kg} \mathrm{~m}^{-3}\right)$. As aforementioned, WP is the total kilograms of yield (fruits in this case) produced by one cubic meter of water. In the presented study, $\mathrm{T} 1$ produced higher yield in terms of kilograms compared to the other applied irrigation scheduling. Yet, it also consumed the highest amount of water compared to T2 and T3. Thus, WP for $\mathrm{T} 1=342\left(\mathrm{~kg} \mathrm{ha}^{-1}\right) / 554.4\left(\mathrm{~m}^{3} \mathrm{ha}^{-1}\right)=0.62 \mathrm{~kg} \mathrm{~m}^{-3}$. While for T2, WP=226 $\left(\mathrm{kg} \mathrm{ha}^{-1}\right) / 16.62\left(\mathrm{~m}^{3} \mathrm{ha}^{-1}\right)=13.60 \mathrm{~kg}$ $\mathrm{m}^{-3}$, and for T3, WP $=227\left(\mathrm{~kg} \mathrm{ha}^{-1}\right) / 12.54\left(\mathrm{~m}^{3} \mathrm{ha}^{-1}\right)$ $=18.13 \mathrm{~kg} \mathrm{~m}^{-3}$. 
Actual evapotranspiration $\left(\mathrm{ET}_{\mathrm{a}}\right)$ is a function of the vegetative growth (Field et al., 1998; Phocaides, 2000) and SWC (Koster et al., 2004; Seneviratne et al., 2006; Seneviratne et al., 2010; Graf et al., 2014; Rahmati et al., 2020). The accumulated $\mathrm{ET}_{\mathrm{a}}$ along 2019-2020 per each applied irrigation scheduling is shown in Figure 6. Mean daily $\mathrm{ET}_{\mathrm{a}}$ was 3.84, 4.65, and $4.80 \mathrm{~mm} \mathrm{day}^{-1}$ for $\mathrm{T} 1, \mathrm{~T} 2$, and $\mathrm{T} 3$ respectively. No significant difference $(\mathrm{P} \leq 0.05)$ in crop coefficient (kc) among the applied irrigation scheduling was found. It was 0.19 in T1, 0.23 in T2 and 0.24 in T3. Obtained $\mathrm{ET}_{\mathrm{a}}$ values were relatively higher than what was reported by Consoli et al. (2013) of $2.5 \mathrm{~mm}$ day ${ }^{1}$. They also estimated higher mean crop coefficient
(0.40) than what was estimated in the current study. Despite the presented study coincides with Consoli et al. (2013) being conducted on O.ficus-indica under Mediterranean climate conditions, microclimate conditions were different. The study of Consoli et al. (2013) was conducted in Italy (north the Mediterranean) were average daily $\mathrm{ET}_{\mathrm{o}}$ during the experiment run was $5 \mathrm{~mm} \mathrm{day}^{-1}$ while average $\mathrm{ET}_{\mathrm{o}}$ of the presented research study was $3 \mathrm{~mm}^{-1 a y^{-1}}$ which might explain different $\mathrm{ET}_{\mathrm{a}}$ estimations (Equation 2). Seneviratne et al. (2010) reported that $\mathrm{ET}_{\mathrm{a}}$ estimation was strongly affected by geographical locations and microclimate conditions.

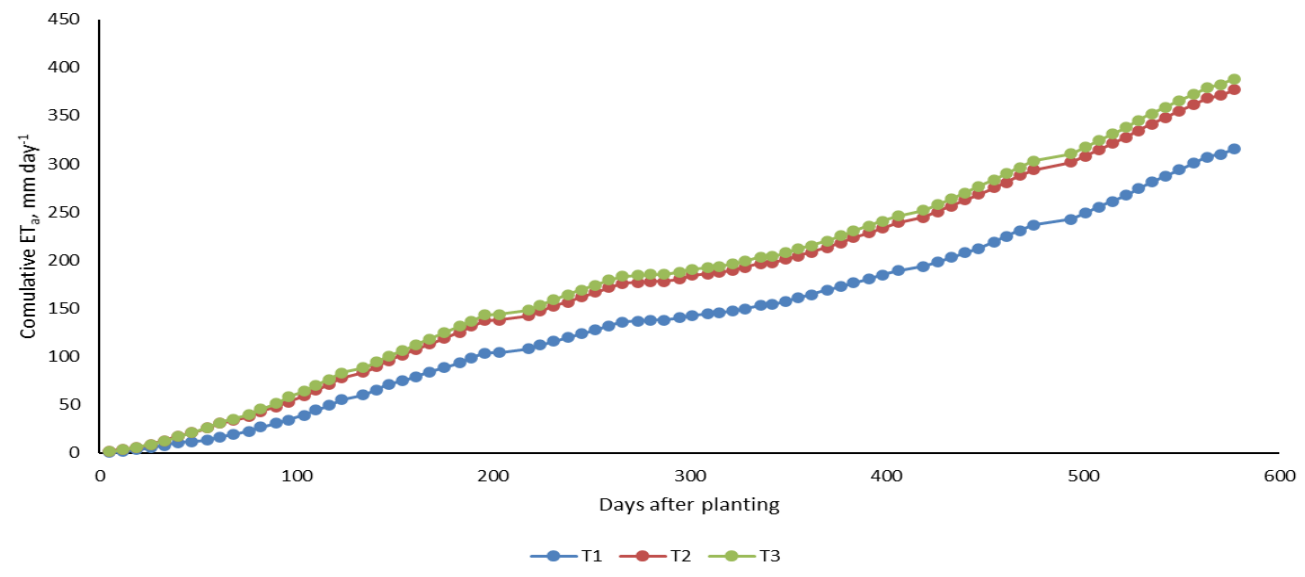

Figure 6. O.ficus-indica accumulated $\mathbf{E T}_{\mathrm{a}}\left(\mathrm{mm}^{\left.-19 y^{-1}\right)}\right.$ during seasons 2019-2020 for each applied irrigation scheduling

Mean $\mathrm{ET}_{\mathrm{a}}$ for $\mathrm{T} 1$ was significantly $(\mathrm{P} \leq 0.05)$ lower than T2 and T3 despite it received the highest amount of applied water (Table 1). No significant difference was found in $\mathrm{ET}_{\mathrm{a}}$ between $\mathrm{T} 2$ and $\mathrm{T} 3$. This coincides with what was observed by Rahmati et al. (2020) who observed that $\mathrm{ET}_{\mathrm{a}}$ did not increase when SWC increased during the years 2017 and 2018 in dry areas. They indicated that precipitation might imply relevant role in this observation. They explained that precipitation events would positively increase SWC values resulting in losing higher portion by deep percolation and driving smaller portion for $\mathrm{ET}_{\mathrm{a}}$ process. In general, the soil climate regime in effective root zone along the study was "Dry". According to Koster et al. (2004) and Seneviratne et al. (2006), SWC in "Wet" and "Dry" regimes did not influence $\mathrm{ET}_{\mathrm{a}}$.

\section{CONCLUSION}

O.ficus-indica can maintain its productivity under severe extended drought conditions. The crop canopy cover development and crop coefficient were not affected by extreme water deficit in effective root zone. The plant evapotranspiration was higher when irrigation was practiced during summer season than being performed on weekly basis. On contrary, weekly irrigation produced higher fruit yield in terms of kilograms per hectare than irrigating only in summer season.

\section{ACKNOWLEGMENT}

Authors would like to acknowledge the generous fund received from the European Union and the Egyptian Science and Technology Development Fund (STDF) through the project ID: ERANETMED3-204 to support the presented research study.

\section{REFERNCE}

Abo-El-Ela AM, Baiuomy MA, Hilal AA (2001). Alternaria rot on plants and fruits of prickly pear in Egypt: Recent outbreak of a destructive disease and its management. Egyptian Journal of Applied Science. 16(9): 93-107.

Alivernini A, Fares S, Ferrara C, Chianucci F (2018). An objective image analysis method for estimation of canopy attributes from digital cover photography. Trees. 32: 713-723. https://doi.org/10.1007/s00468-018-1666-3

Allen RG, Pereira LS, Raes D, Smith M (1998). Crop evapotranspiration - Guidelines for computing crop water requirements - FAO Irrigation and 
Drainage Paper 56, Food and Agricultural Organization of the United Nations, Rome, Italy.

Ammar MI, Shltout AM, Kamhawy MA (2004). Cladode and fruit rots of prickly pear (Opuntia ficusIndica L. Mill.) in Egypt. Egyptian Journal of Phytopathology. 32(1-2), 119-128.

Bakr AA (2019). Impact of partial replacement of alfalfa hay with prickly pear peels (PPPS) on productive performance of rabbits. Egyptian Journal of Nutrition and Feeds. 22(3): 535-550.

CAAES (2005). Cultivation and production of cactus pear. Central Administration for Agricultural Extension Services, Ministry of Agriculture and Land Reclamation, Report no.993/2005, Cairo.

Consoli S, Inglese G, Inglese $P$ (2013). Determination of evapotranspiration and annual biomass productivity of cactus pear (Opuntia ficusindica L. (Mill.)). Journal of Irrigation and Drainage Engineering, 139(8): 680-690. doi: 10.1061/(ASCE)IR.1943-4774.0000589

Souza JAA, dos Santos DB, Donato SLR (2020). Yield and survival rate of "Gigante" cactus pear under regulated deficit irrigation using wastewater. Research Square, https://doi.org/10.21203/rs.3.rs63234/v1

Duffková R, Zajíček A, Nováková E (2011). Actual evapotranspiration from partially tile-drained fields as influenced by soil properties, terrain and crop. Soil and Water Research. 6(13): 131-146. https://doi.org/10.17221/20/2010-SWR

Estefan G, Sommer R, Ryan J (2013). Methods of soil, plant, and water analysis: A manual for the west Asia and north Africa region. Third edition. International Center for Agricultural Research in the Dry Areas (ICARDA), Lebanon.

Field WP, Collier FW, Wallingford HR (1998). Checklist to assist preparation of small-scale irrigation projects in sub-Saharan Africa. International commission on irrigation and drainage in cooperation with Department of International Development and Food and Agriculture Organization of the United Nations.

Filgueiras R, Almeida TS, Mantovani EC, Dias SHB, Fernandes-Filho EI, de Cunha FF, Venancio LP (2020). Soil water content and actual evapotranspiration predictions using regression algorithms and remote sensing data. Agricultural Water Management, 241. https://doi.org/10.1016/j.agwat.2020.106346.

Graf A, Bogena HR, Drüe C, Hardelauf H, Pütz T, Heinemann G, Vereecken H (2014). Spatiotemporal relations between water budget components and soil water content in a forested tributary catchment. Water Resources Research, 50(6): 4837-4857. http://dx.doi.org/10.1002/2013WR014516

Hassan S, Liguori G, Paolo I, Mounir L, Sortino G (2020). The effect of soil volume availability on
Opuntia ficus-indica canopy and root growth. Agronomy, 10(5): 635. https://doi.org/10.3390/agronomy 10050635

Inglese P, Mondragon C, Nefzaoui A, Sáenz C (2017). Crop ecology, cultivation and uses of cactus pear. IX International Congress on Cactus Pear and Cochineal: CAM crops for a hotter and drier world. The Food and Agriculture Organization of the United Nations (FAO) and the International Center for Agricultural Research in the Dry Areas (ICARDA), Rome, Italy.

Israelsen OW, Hansen VE (1962). Flow of water into and through soils: Irrigation principles and practices. 3rd Edition. John Wiley and sons, Inc., New York, USA.

Jung M, Reichstein M, Ciais P, Seneviratne SI, Sheffield J, Goulden ML, Bonan G, Cescatti A, Chen J, de Jeu R, Dolman AJ, Eugster W, Gerten D, Gianelle D, Gobron N, Heinke J, Kimball J, Law BE, Montagnani L, Mu Q., Mueller B, Oleson $\mathrm{K}$, Papale D, Richardson AD, Roupsard O, Running S, Tomelleri E, Viovy N, Weber U, Williams C, Wood E, Zaehle S, Zhang K (2010). Recent decline in the global land evapotranspiration trend due to limited moisture supply. Nature, 467: 951-954. https://doi.org/10.1038/nature09396

Khalafalla AA, Said WM, Mohamed SY, Al Saidi FM (2016). Diversity and vegetation analysis of plant species associated with prickly pear (Opuntia ficus indica L. Mill.) in Nile Delta, Egypt. Journal of Scientific Research in Science. 33(1): 1-21. https://dx.doi.org/10.21608/jsrs.2016.15620.

Kiesling $\mathbf{R}$ (1998). Origen, domesticación y distribución de Opuntia ficus-indica. Journal of the Professional Association for Cactus Development. 3: 50-59.

Korhonen L, Heikkinen J (2009). Automated analysis of in situ canopy images for the estimation of forest canopy cover. Forest Science. 55(4): 323-334.

Koster RD, Dirmeyer PA, Guo ZC, Bonan G, Chan E, Cox P, Gordon CT, Kanae S, Kowalczyk E, Lawrence D, Liu P, Lu CH, Malyshev S, McAvaney B, Mitchell K, Mocko D, Oki T, Oleson K, Pitman A, Sud YC, Taylor CM, Verseghy D, Vasic R, Xue YK, Yamada T (2004). Regions of strong coupling between soil moisture and precipitation. Science 305: 1138-1140.

Kumar K, Singh D, Singh RS (2018). Cactus pear: Cultivation and uses. CIAH technical report No. 73. Central Institute for Arid Horticulture. Bikaner, Rajasthan, India.

Lee KJ, Lee BW (2011). Estimating canopy cover from color digital camera image of rice field. Journal of Crop Science and Biotechnology. 14: 151-155. https://doi.org/10.1007/s12892-011-0029-z

Liguori G, Inglese $P$ (2015). Cactus pear fruit production: Orchard planting and management of 
Opuntia ficus-indica. in Waal, H., Louhaichi, M., Taguchi, M., Fouché, H., Wit, M., (Eds.). Development of a cactus pear agro-industry for the sub-Sahara Africa region. CACTUSNET Newsletter Special Issue 14. Proceedings of International Cactus Pear Workshop held at the University of the Free State (UFS), Bloemfontein, South Africa, 27-28 January.

Liu Y, Liu Y, Chen M, Labat D, Li Y, Bian X, Ding $Q$ (2019). Characteristics and drivers reference evapotranspiration in Hilly regions in southern China. Water, 11(9):

2-21. https://doi.org/10.3390/w11091914

MALR (2014). Bulletin of agricultural statistics 1990-2013. Economic Affairs Sector, Central Department of Agrarian Economics and Statistics, Egyptian Ministry of Agriculture and Land Reclamation, Cairo, Egypt.

Michael AM (2006). Irrigation theory and practice. In: Soil-Plant-Water Relationships. Vikas Publishing House Pvt. Ltd, New Delhi, India, pp. 448-584.

Molden D., Murray-Rust H., Sakthivadivel R., Makin I. (2003). A water productivity framework for understanding and action. In: Kijne, J.W., Barker, R., Molden, D., Water productivity in agriculture limits and opportunities for improvement. International Water Management Institute, CAB International.

MWRI (2014). Water scarcity in Egypt: The urgent need for regional cooperation among the Nile basin countries. Egyptian Ministry of Water Resources and Irrigation, Cairo, Egypt.

Najjar D (2015). Women's contribution to climate change adaptation in Egypt's Mubarak Resettlement Scheme through cactus cultivation and adjusted irrigation. In: Buechler, S., Hanson, A.S. (Eds). A political ecology of women, water and global environmental change. Taylor and Francis (Routledge), New York, USA.

North GB, Nobel PS (1992). Drought-induced changes in hydraulic conductivity and structure in roots of Ferocactus acanthodes and Opuntia ficusindica. New Phytologist. 120 (1): 9-19. https://doi.org/10.1111/j.1469-8137.1992.tb01053.x Passioura JB (1988). Water transport in and to roots. Annual Review of Plant Physiology and Plant Molecular Bilogoy. 39: 245-265. https://doi.org/10.1146/annurev.pp.39.060188.00133 3
Phocaides A (2000). Technical Handbook on Pressurized Irrigation Techniques. Food and Agriculture Organization of the United Nations (FAO), Rome, Italy

Rahmati M, Groh J, Graf A, Pütz T, Vanderborght $J$, Vereecken $H$ (2020). On the impact of increasing drought on the relationship between soil water content and evapotranspiration of a grassland. Vadose Zone Journal, 19(1): 1-20. https://doi.org/10.1002/vzj2.20029

Sáenz C, Berger H, Rodríguez-Félix A, Galletti L, García JC, Sepúlveda E, Varnero MT, García de Cortázar V, Carcía RC, Arias E, Mondragón C, Higuera I, Rosell C (2013). Agro-Industrial utilization of cactus pear. Rural Infrastructure and Agro-Industries Division, Food and Agricultural Organization of the United Nations, Rome, Italy.

Seneviratne SI, Corti T, Davin EL, Hirschi M, Jeger EB, Lehner I, Orlowsky B, Jeuling AJ (2010). Investigating soil moisture-climate interactions in a changing climate: A review. EarthScience Reviews, 99(3-4): 125-161. https://doi.org/10.1016/j.earscirev.2010.02.004

Seneviratne SI, Luthi D, Litschi M, Schar C (2006) Land-atmosphere coupling and climate change in Europe. Nature 443: 205-209

Snyman HA (2005). A case study on in situ rooting profiles and water-use efficiency of cactus pears, Opuntia ficus-indica and O. robusta. Journal of the Professional Association for Cactus Development. $7: 1-21$.

USDA (2020). Estimating soil moisture by feel and appearance. United States Department of Agriculture, Natural Resources Conservation Service, Program Aid number 1619, USA. Available online https://www.nrcs.usda.gov/Internet/FSE_DOCUME NTS/nrcs144p2_051845.pdf. Last Accessed November, $15^{\text {th }} 2020$.

Wang X, Liu H, Zhang L, Zhang R (2014). Climate change trend and its effects on reference evapotranspiration at Linhe Station, Hetao Irrigation District. Water Science and Engineering, 7(3): 250266. doi:10.3882/j.issn.1674-2370.2014.03.002

Xiong Y, West CP, Brown CP, Green PE (2019). Digital image analysis of old world bluestem cover to estimate canopy development. Agronomy Journal. $111 \quad$ (3): 1247-1253. https://doi.org/10.2134/agronj2018.08.0502 
تأثير جدولة الري على نمو الغطاء النباتي ومعايير إدارة المياه على مستوى الحقل لنبات التين الثوكي تحت الظروف المناخية الجافة في منطقة البحرالمتوسط النطائ (Opuntia ficus-indica)

مها البناء1، إيمان الجمل2، عبداله محمد²، آنا لويزا فرناندو3، لويجي باري4، عبدالقادر أوتزوريت5، محمود الوكيل6، وائل

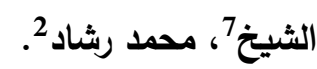

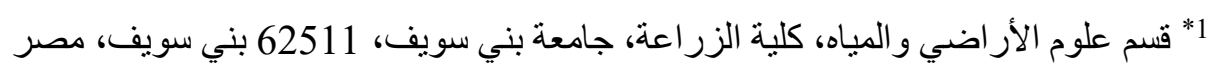

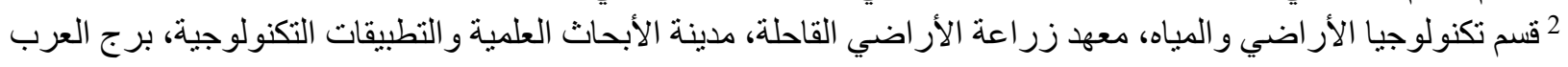

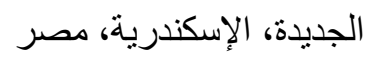
3 الجامعة الجديدة بلثبونة، كلية العلوم و التكنولوجيا، قسم علوم وتكنولوجيا الكتلة الحيوية، وحدة التكنولوجيا الحيوية و البيئية،

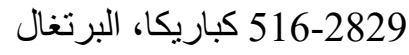
4 مجلس البحوث الزراعية والاقتصاد، مركز البحوث الهنسية وتصنيع الأغذية الزراعية، طريق باسكو لاري 16,00015 مونتيروتوندو ، إيطاليا

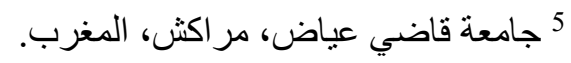

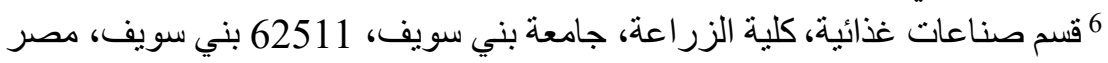

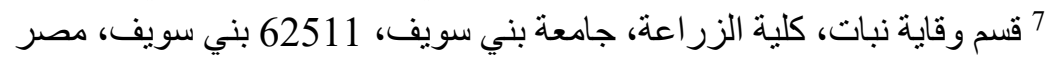

نجح نبات التين الشوكي (Opuntia ficus-indica) مؤخرا في جذب انتباه العلماء وصناع القرار على مستوى العالم كمحصول

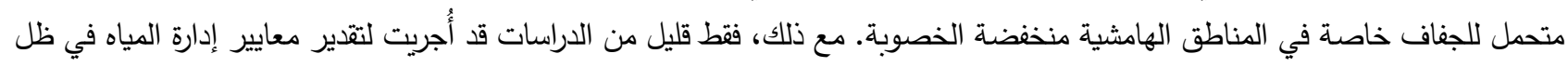

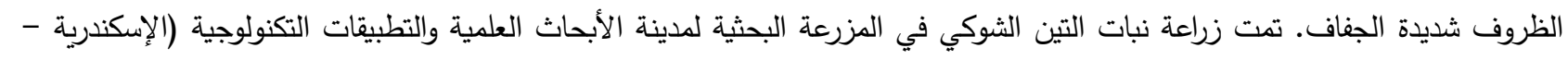

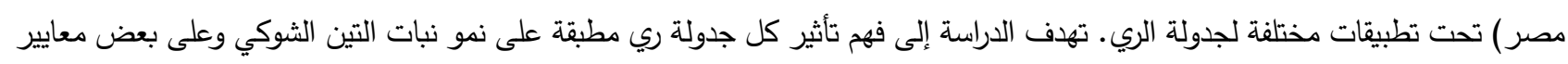

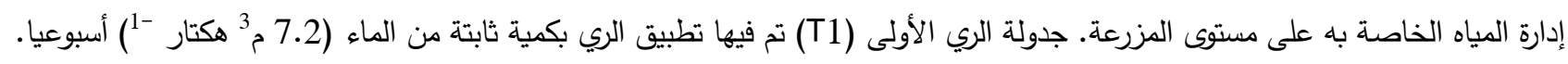

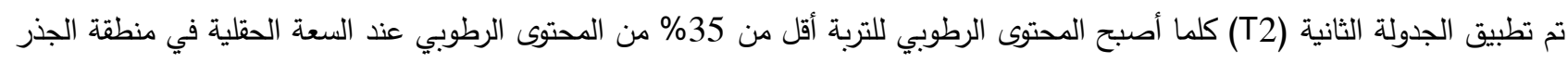

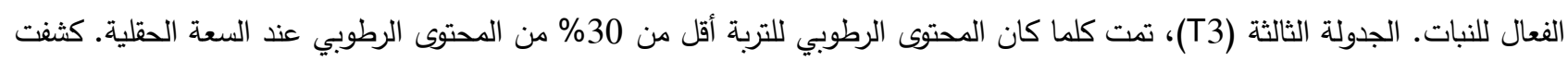

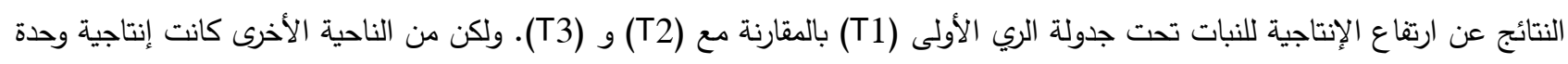

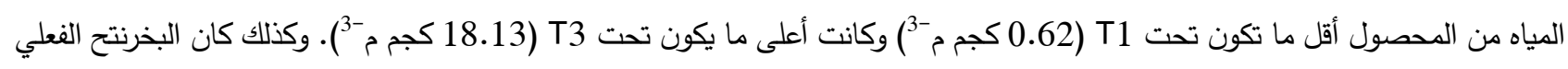

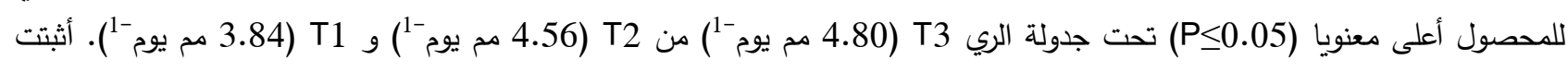

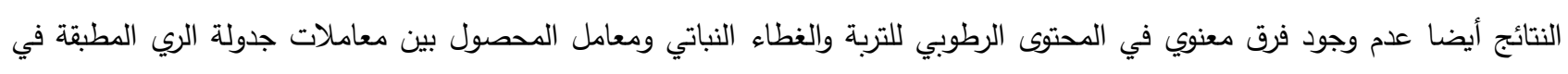

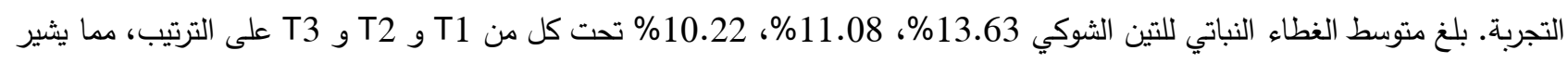

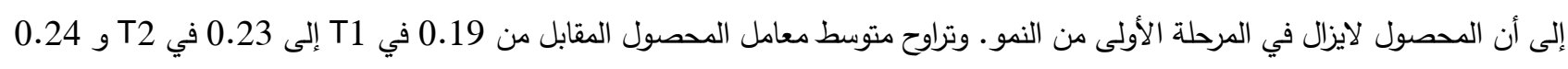

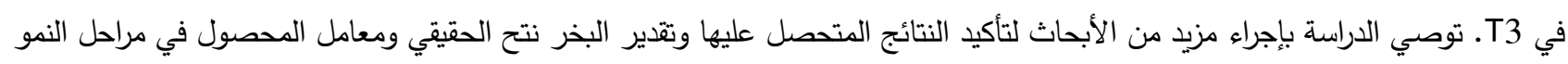
المتوسطة والنهائية للنبات. 